\title{
Exporting Deregulation - Alfred Kahn and the Celtic Tiger
}

\author{
SEAN D. BARRETT * \\ Department of Economics, Trinity College, Dublin 2, Ireland
}

\begin{abstract}
Airline deregulation in Ireland arose from a parliamentary revolt in 1984 against legislation to imprison and fine those selling airline tickets below government approved fares. The revolt was heavily influenced by US airline deregulation in 1978 and the writings of Alfred Kahn. The results were spectacular. Dublin-London, deregulated in 1986, became the busiest international route in Europe. The $2.2 \mathrm{~m}$ passengers on the Irish national airline before deregulation in 1986 increased to $72 \mathrm{~m}$ passengers on four Irish airlines in 2008. Ryanair redefined the European aviation. The success of airline deregulation had a major influence on Irish economic policy
\end{abstract}

\section{Introduction}

Alfred Kahn's visit to Ireland in October 2006 was a remarkable tour de force. He addressed the annual economic policy conference of economists, senior public servants and financial sector executives at Kenmare where celebrated his $89^{\text {th }}$ birthday. He lectured to packed halls of undergraduates in Trinity College, Dublin. He lived on campus, entered into the spirit of traditional events such as choral evensong and held briefings on competition issues for senior Irish regulators. Scores of undergraduate examination scripts in that academic year included phrases such like "as Alfred Kahn said on his visit last October".

Kahn's visit was no empty ceremonial occasion. No country adopted more enthusiastically than Ireland the policy of airline deregulation developed by Alfred Kahn and promoted by President Carter and Senator Edward Kennedy. No country had more dramatic results from aviation deregulation than Ireland. In this special issue of the Review of Network Economics commemorating the economic and public policy contributions of Alfred Kahn, the export of his ideas to Ireland is an important case study. The sole Irish national airline had 2.2 million passengers in 1985/6, the last full year before deregulation in May 1986. In 2008, the four Irish airlines in the deregulated market have 72 million passengers. Airline deregulation was the first step in a series of changes in Irish economic policy, which led to the so-called Celtic Tiger era of rapid economic growth described in Table 7. The successive themes of this paper in sections 2, 3 and 4 below are the regulatory capture of aviation policy by Europe's national airlines, the stagnation before deregulation and the case made by Aer Lingus to exclude new market entrants from Irish aviation.

\footnotetext{
* Department of Economics, Trinity College, Dublin,2, Ireland. E-mail: sbarrett@tcd.ie I appreciate the
} helpful comments of the editors and referees but the usual disclaimer applies. All errors are mine. 
Section 5 describes a unique parliamentary revolt against protectionism in aviation. Section 6 documents the opposition of Irish economists to protectionism in aviation. Section 7 documents the policy reversal in favour of deregulation. Section 8 asks whether Irish aviation deregulation has been the most spectacular yet seen in terms of reduced fares and increased passenger numbers. Section 9 examines the erosion of economic rents due to market entry by Ryanair. Section 10 examines the influence of the success of airline deregulation on wider economic policies in Ireland leading to the Celtic Tiger era. Section 11 reflects on the successful export of Alfred Kahn's deregulation policy to Ireland. The concluding section deals with the power of ideas in conflict with entrenched vested interests and the economist in the service of the wider community.

\section{Europe's national airlines - from national policy instrument to regulatory capture.}

Ireland is an outer offshore island, which depends heavily on aviation for its trade and tourism. With the benefits of airline deregulation so obvious since 1986, the case is strong that Ireland should have supported open skies at the Chicago conference in 1944 when the regulatory framework for post-war aviation was established. Fears that the USA would dominate aviation under open skies led European countries to opt instead for a system of restrictive bilateral aviation agreements. Air travel between two countries was subject to agreement between two governments and was confined to one airline per country operating at stipulated prices and with control of supply under market sharing agreements.

The readiness of European governments to adopt the national airline model reflected protectionist and nationalistic goals initially but over time these goals were supplanted by regulatory capture of aviation ministries by the national airlines and the identification of the national interest with the national airline interest. Regulatory capture describes situations in which government regulatory agencies created to serve the public interest instead act in favour of the commercial or special interests that dominate the sector they are charged with regulating.

In Europe, national airlines attained capture over aviation regulation at the expense of consumers. While in the US the term regulatory capture in aviation referred to the capture by private companies of regulation of the sector, in Europe regulatory capture in aviation referred to the control of the market by national airlines in the producer rather than consumer interest. New market entrants were excluded and price competition between incumbents was prohibited. Public ownership of Europe's national airlines facilitated regulatory capture by generating political leverage by the portrayal of national airlines as symbols of national development and political patronage through the appointments to airline boards by transport ministers. While there may have been initial aspirations that national airlines would indeed serve the wider national interest, the case made here is that regulatory capture in European aviation was thorough. National airlines controlled aviation policy by regulatory capture of transport departments. The economic rents generated by this capture were absorbed in low labour productivity and higher pay and the cost was high air fares. Both the productivity and fares were to change radically when the market was later deregulated.

Consumers were largely indifferent to the lack of competition between airlines operating within mainland Europe where road and rail travel were available. In the outer 
European counties, the consumer interest in competition in aviation was partially satisfied by the licensing of charter airlines serving holiday destinations. A two-tier aviation system developed. Routes to Mediterranean resorts were operated by charter airlines at fares at about a third per mile of the fares charged by the designated national airlines on routes serving the remainder of the European market. International air fares on the latter routes were the most expensive in the world according to the annual ICAO surveys.

On the North Atlantic route, Irish regulatory authorities excluded American airlines from Dublin for twenty-eight years up to 1973 by designating Shannon as the airport for traffic between North America and Ireland. The Dublin market was reserved for Aer Lingus. The device used to support this protectionism for Aer Lingus was to divide the airline into two entities. Aer Linte operated on the Atlantic portion of the journey. The aircraft then became an Aer Lingus flight between Dublin and the compulsory stop at Shannon in what was euphemistically called an "interchange agreement" between Aer Linte and Aer Lingus. From 1983 to 2008, both Aer Lingus and North American airlines en route to and from Dublin were compelled to serve Shannon also. The EU/USA open skies agreement in 2008 finally ended the strong protectionist emphasis in Irish aviation policy.

Examples of the anticompetitive stance of the Irish regulatory authorities between 1982 and 1984 are seen in the Department of Transport's correspondence with Transamerica Airlines. On October 11, the Department informed the airline that

"With effect from Ist October increases of 12\% on all ex Ireland rates and 7\% on current ex Europe rates have been approved by the Minister. Accordingly the new economy fare level on the ShannonAmsterdam route is IR£156 one-way and IR£312 return. In the circumstances the levels currently filed by Transamerica cannot be approved but a revised filing, reflecting the aforementioned increases, would be welcomed at your earliest convenience.

A telex from the Department of Transport to Transamerica on December 23, 1983 disallowed a \$449 fare from New York to Shannon as “disruptive and a cause of fundamental concern in terms of the entire US-Ireland scheduled fare structure and in turn for the viability of year round scheduled services. We note that the fare is 80 dollars below the level which prevailed in summer 1983 and fail to see any justification for the reduction, given current trends in airline costs, both for US and European carriers, the prevailing competitive scene in adjacent markets etc.”

The Department also stated that:

"This administration also has serious reservations about other elements of the fares filing in particular the YPO USD $299 \mathrm{JFK} / \mathrm{SNN}$ fare the setting of Apex and economy fares at the same levels for SFO or LAX/SNN (a principle totally unacceptable to us) and the general tariff structure and tariff levels proposed for fares ex Ireland.”

"We believe that the overall interests of market stability would be facilitated by further inter-airline consultations and we would like to see an early resumption of the tariff co-ordination discussions that were begun in New York in October. We would, of course, be available for direct discussions. In the meantime this administration is suspending further consideration of the entire fares filing."

A telex on April 4, 1984 disallowed one-way pex and apex fares because "fares of this type should meet the normal excursion requirements of a round-trip operation".

The Transamerica correspondence (Transamerica Airlines, 1984) from the Irish regulatory authorities shows that, some six years after deregulation in the US, its fares were being rejected by the Irish authorities because they were too low, that they were required to implement Aer Lingus fare increases "at your earliest convenience" and that it 
was Irish government policy to have inter-airline tariff co-ordination discussions despite the collusive dangers of such discussions.

Ireland presented a pronounced case of regulatory capture of the transport department by the national airline, Aer Lingus. The airline was invoked as a means to exclude new market entrants even before Aer Lingus was established in 1937. The airline was also successful in every decade up to the late 1980s in securing the exclusion of new entrants from the Irish aviation market. In the words of its critics, the Department of Transport acted as a "downtown office" of Aer Lingus, refusing market access to independent airlines and operating a weak regime of price control over airline fares. Table 1 shows examples of decisions to refuse market access to new entrant airlines.

\begin{tabular}{|c|c|c|c|}
\hline Year & Applicant & Routes denied & Reasons for refusals \\
\hline 1935 & Crilly & Ireland/UK & Intention to establish a national airline \\
\hline $\begin{array}{l}1945- \\
73\end{array}$ & $\begin{array}{l}\text { US } \\
\text { Airlines }\end{array}$ & USA-Dublin & Protecting Aer Lingus and Shannon \\
\hline $\begin{array}{l}1945- \\
73\end{array}$ & Canadian & Canada-Dublin & Protecting Aer Lingus and Shannon \\
\hline $\begin{array}{l}1945- \\
2008\end{array}$ & All & $\begin{array}{l}\text { North America- } \\
\text { Dublin }\end{array}$ & Protecting Shannon by compulsory stop \\
\hline $\begin{array}{l}1946- \\
86\end{array}$ & $\begin{array}{l}\text { UK } \\
\text { Charters }\end{array}$ & UK-Ireland & Irish Sea routes monopoly for Aer Lingus \\
\hline 1949 & Cambrian & Cork-UK & $\begin{array}{l}\text { Policy "did not contemplate" airlines other } \\
\text { than Aer Lingus on Ireland/UK routes }\end{array}$ \\
\hline 1949 & Avio Linee & $\begin{array}{l}\text { Dublin-Milan } \\
\text { via Paris }\end{array}$ & Dublin-Paris reserved for Air France \\
\hline 1950 & $\begin{array}{l}\text { Linee } \\
\text { Aeree }\end{array}$ & $\begin{array}{l}\text { Dublin-Rome } \\
\text { via Paris }\end{array}$ & Same reason as Dublin-Milan refusal \\
\hline 1950 & Silver City & $\begin{array}{l}\text { Dublin- } \\
\text { Liverpool }\end{array}$ & Aer Lingus “considering” the route \\
\hline
\end{tabular}

Table 1: Refusals of market entry by Irish aviation regulators, 1935-2008

Source: Based on Share (1968, pp. 3 and 68-71).

The degree of regulatory capture of the Department of Transport by Aer Lingus is illustrated also by the reaction of Aer Lingus to the licensing of Ryanair on the DublinLondon route in 1986. The Aer Lingus chairman's report for 1985/6 (p. 8) stated that

"The decisions of the regulatory authority at home have the utmost significance for us. The awarding of a licence to an additional recently founded Irish carrier between Dublin and London was a critical decision. With the possible exception of the Atlantic route at some time in the future, Dublin-London is the only route on the Aer Lingus network that has the volume of business to allow of itself a reasonable return on capital. The decision to put a fourth carrier on the route will have an effect on Aer Lingus' ability to earn enough profit to attract capital needed for fleet renewal and for further development. It will also affect the ability of Aer Lingus' to operate those marginal Cross-Channel and Continental routes where little or no return can be earned. The advent of this carrier on the route has brought about the usual predatory pricing phase while it attempts to take over market share and this phase has yet to run its course. Further applications have, as we expected, now come for relaxation of conditions set out in the Dublin-London licence and for 
operations on further segments of Aer Lingus' few profitable routes. We also request consideration from the licensing authorities at home of further dilution on the precarious markets we serve.”

The added problem in the public ownership of Europe's protected airlines was distressed state airline syndrome (Doganis, 2001) the elements of which are shown in Table 2. State airlines became dominated by political factors such as the appointment of their boards and interference in their operations by government ministers. Airline management and staff became skilled at influencing governments and resisting innovation and productivity improvements. Airlines in state ownership did not face a bankruptcy constraint. This made product and productivity improvements difficult to attain. Weak regulatory control over national airlines suited both management and staff and consumer opposition was weak by comparison. A stricter regulatory regime resulting in losses at the airline ran the risk of the wrath of the Department of Finance, which would have to raise taxes to meet the losses of a state company.

\begin{tabular}{|l|}
\hline a) Substantial losses \\
\hline b) Overpoliticisation \\
\hline c) Strong unions \\
\hline d) Overstaffing \\
\hline e) No clear development strategy \\
\hline f) Bureaucratic management \\
\hline g) Poor service quality \\
\hline
\end{tabular}

Table 2: Distressed state airline syndrome

Source: Doganis (2001).

A further difficulty for consumers was that Aer Lingus became a national symbol in the 1930s in a newly independent Ireland. It became in its own image a section of the diplomatic corps, a tourism promotion agency, a promoter of Ireland's image abroad, a presence in the main streets of major cities in many parts of the world and a symbol of a new nation on an international stage. Public enterprises such as Aer Lingus moved from being chosen instruments of public policy and development corporations to control of public policy in their own interest and barriers to economic development. Lee (1989, p.536) notes that by the early 1980s

"The public had so lost confidence in the ability of any state organisation to serve any purpose except its own self-interest that the proposal (for a National Development Corporation) generated more scepticism than enthusiasm. A series of poor returns on several enterprises and the apparent casualness with which public sector trade unions resorted to the tactic of inflicting suffering on the public, the same public they claimed to serve in their more esoteric flights of rhetorical fancy, in order to intimidate the government into concessions left public opinion increasingly dubious about the likely results of state intervention."

The Irish case of regulatory capture by the national airline was arguably the most comprehensive in Western Europe because of both its scope and its extent. The scope of regulatory capture in Ireland is illustrated in its application to charter airlines as well as to scheduled airlines and the prohibition on US and Canadian airlines from serving the capital city, Dublin. Charter airlines in Europe charged fares of only a third of the high cost scheduled air fares. The charter model was successfully operated on many European routes to meet the demand for low cost holiday air travel but not by Ireland. In its major market, 
Ireland-United Kingdom, the charter share was 1\% in 1986 compared to $82 \%$ between the United Kingdom and Spain. Ireland maintained a fictional distinction between Aer Lingus and Aer Linte in order to restrict access by North American airlines to its capital city, Dublin, a policy that was also unique in Europe. The administrative, legal and emergency parliamentary actions against Transamerica also indicate the regulatory strength of feeling against competition in aviation in Ireland.

The extent of the negative impact of a policy is illustrated by the results when the policy is jettisoned. The end of regulatory capture in Irish aviation policy resulted in large fare reductions, and large output and productivity increases. Tables 4 and 5 below show that fares fell by $54 \%$ on the first day of deregulation and passenger numbers increased by $65 \%$ in the first year of deregulation on the Dublin-London route. The favored company, Aer Lingus, had 2.2 million passengers in 1985/6, after 50 years of protectionism. The 2008 passenger numbers for the four Irish airlines are estimated at 72 million passengers, comprising 58 million for Ryanair, 10.5 million for Aer Lingus, 1.8 million for Cityjet and $1.5 \mathrm{~m}$ for Aer Arann. The deregulated Irish aviation sector is 33 times greater than the protected one. The favored airline, Aer Lingus, has fallen from 100\% market share to $14.6 \%$ despite increasing its passenger numbers by 4.8 times. The two small airlines, Cityjet and Aer Arann, with 3.3 million passengers, are 50\% bigger than the "national airline” was after fifty years of protection in 1986. Ryanair in 2008 has 5.5 times the passenger numbers of Aer Lingus, the highest ratio of a new entrant airline to its former national carrier in Europe. The rapid growth of Irish airlines after deregulation and the decline in the share of Aer Lingus strengthen the case that the previous regulatory capture of policy by the national airline had more detrimental impacts in Ireland than elsewhere in Europe. Further, as shown in Table 7 below, the success of the Irish economy after airline deregulation saw total employment in the economy increase by $82 \%$ while the share of state companies in total employment declined by $75 \%$.

In summary, the consensus in Ireland on the eve of deregulation was that Aer Lingus had achieved regulatory capture over national aviation policy and that this capture had harmed the national economy. Whereas the Kennedy hearings in the US showed the CAB to be "a somewhat disorganised group of administrators unable to articulate any coherent, convincing rationale for many of the policies they had followed” (Breyer, p.338), the Irish aviation authorities served the national airline interest so strongly that they were described as a "downtown office” of Aer Lingus.

\section{Stagnation before deregulation}

The weak Irish economy resulted in heavy emigration in the 1970s and 1980s. Emigrants returning to Ireland at short notice were major critics of the high cost of air travel. As residents abroad however this group was able to exert very little influence on Irish aviation regulators against the dominant influence of the management and employees of the national airline. Ireland was thus among the least likely countries in the OECD to seek to follow the USA example of airline deregulation in 1978. Factors such as regulatory capture, a weak regulatory authority, weak consumer interests, and several illusions and delusions inherited from the protectionist era of economic nationalism were firm bulwarks against market forces in the sector. Table 3 illustrates the world of high fares and low volumes in the most tightly controlled aviation market in Western Europe. 
Table 3 shows that London-Dublin had the highest rate of fare increase, $72.5 \%$, and the lowest rate of passenger number increase, $2.8 \%$ over the pre-deregulation half-decade of 1980-1985. By contrast, fares fell by 54.2\% on deregulation day in 1986 and passenger numbers in 1987, the first full year of deregulation, were $64.9 \%$ more than in 1985 . This contrast is shown in Table 4.

\begin{tabular}{|l|l|l|}
\hline London to & Fare Increase (\%) & Passenger Growth (\%) \\
\hline Dublin & 72.5 & 2.8 \\
\hline Amsterdam & 38.5 & 24.1 \\
\hline Paris & 63.2 & 17.1 \\
\hline Frankfurt & 43.2 & 40.1 \\
\hline Brussels & 43.6 & 20.4 \\
\hline Glasgow & 31.9 & 40.4 \\
\hline Edinburgh & 31.9 & 58.3 \\
\hline Belfast & 40.9 & 30.7 \\
\hline Manchester & 45.4 & 41.9 \\
\hline Aberdeen & 29.2 & 34.5 \\
\hline Newcastle & 38.8 & 18.4 \\
\hline Average (11 routes) & 43.7 & 29.9 \\
\hline London-Dublin Index* & $166^{*}$ & $9 *$ \\
\hline
\end{tabular}

Table 3: Pre-deregulation fare increases and passenger growth on London-Dublin and ten short haul routes ex London, 1980-1985

Note: The Retail Price Index increased by 41.5\% between 1980 and 1985 . * Index based on the average of 100 for the eleven routes for both fare and passenger number growth. The London-Dublin fare increased by $66 \%$ more than the average for the eleven routes while the growth in passengers was $9 \%$ of the average for the eleven routes. Source: Barrett (1990).

\section{$4 \quad$ Defending the Status Quo - The pre-deregulation policy stance}

In June 1981, a strong attack on US aviation and wider economic policies was made at the Lloyds International civil aviation conference in Paris by the Aer Lingus chief executive. He saw competition between US and European airlines on the Atlantic routes as partly ideological, a confrontation between

\footnotetext{
"The social objectives shared by the governments of most of Europe and those of the United States where a hire-and-fire system of employment still operates generally ... The outcome of this clash of ideologies had been predatory and destructive competition, stimulated not by business initiative but by the missionary fervour of certain regulatory agencies. The important concept of public utility has been abandoned by these zealots and replaced by short-sighted consumerism ... monumental confusion reigns with airlines offering a bewildering variety of fares which they change so often that not even their own sales offices can be sure what today's tariff may be. Advocates of this super competitive regime admit this is true but claim that the bargain fares available to travellers are worth the trouble ... The economics of the industry are being undermined in order to provide consumers with fares lower than they can afford and lower also than the value to those consumers of the service received.” (Share, 1986, pp.233-234)
} 
This antipathy to markets was frequently accompanied by confusion about the operation of the same markets as seen in successive sentences in the official history of Aer Lingus (Share, 1986, pp.235-236).

"No amount of fare-juggling could, however, conceal the fact that the Atlantic was, in the climate of the 1970s, irremediably uneconomic, and for a small airline like Aer Lingus with no other longhaul routes to provide balancing profits, disastrously so. There was no clear commercial advantage to be gained by pulling off the Atlantic, David Kennedy told his Board in September 1976.”

Barrett and Curran (1984) compared air fares in April 1984 on eight journey lengths in Europe and the United States. The fare differentials were so large that we advocated airline deregulation in Europe, following the US example in 1978, under the title 'How to Halve the Cost of Air Fares in Europe'. The title of the article was in fact conservative since the Dublin-London air fare was four times the per mile rate on New York-Buffalo and San Francisco-Los Angeles.

The commercial barriers to entry in aviation are small. Aircraft can be leased at short notice. Airport managers are delighted to talk to new customers for their services. The obstacle is the regulator. European governments have a veto on new entrants since everything in aviation is forbidden unless you can get a licence. Licences are rarely given to anyone except the national carriers.

We noted the minimal progress of airline deregulation in Europe since 1979 and the proposal by the EU in March 1984 to exempt airlines from the competition policy provisions of the Treaty of Rome. In 1984, only the United Kingdom and the Netherlands supported market liberalisation in European aviation.

The Aer Lingus response (October 1984) was that "Europe's air fares are just about right" and that "overall, for consumers and airlines, deregulation is not a panacea and certainly gives no basis for believing that the cost of air fares in Europe can be halved". The response also stated that our fare comparisons "showed an extraordinary degree of bias that brings into question the objectivity of the authors and doubts about their motivation”. The Aer Lingus product was claimed to be superior to no frills airlines in the USA. European fares should be compared with routes of comparable frequency such as New York/Richmond rather than with San Francisco-Los Angeles. Other points were that the US had uncompetitive as well as competitive routes since deregulation; that Europe had developed an extensive route network and high quality services; that European air fares "are not in most cases unreasonably related to airline costs"; that flights within Europe are international "with implications for airport design; that deregulation does not benefit passengers on low to medium density and length of haul routes; and that deregulation led to bankruptcies".

The Barrett/Curran reply (December 1984) stated that the low fare Peoples Express was "precisely the type of airline which the European regulatory system is designed to prevent coming into operation" and that air fares in California had been low because of liberal regulation there. In the event the first major European deregulation, the DublinLondon route in 1986, did result in a halving of air fares. The route became a major high density one and ranked with the highest volume international routes worldwide and adopted the no frills model while the high costs of European aviation were reduced by large increases in productivity initiated by low cost carriers but largely adopted by national airlines some time later.

A most unusual parliamentary revolt changed Ireland from a strong opponent of European airline deregulation to proponent. Ireland became an innovator in aviation with 
first mover advantage from the 1986 deregulation some eleven years before the European deregulation of 1997. The policy shift from conservative to radical required a unique parliamentary revolt in June 1984, which is examined in section 5 below.

The superiority of a "national carrier" over mere commercial airlines and the indispensability of national airlines to attaining national goals, many of them obscure, are seen in an article in Cara by the Aer Lingus Chief Executive in September/October 1986. Writing in the company publication Cara after some three months of competition between Dublin and London, the Chief Executive states that

"As the national carrier our concern is to operate the widest possible range of fairly-priced services on all practicable routes to the very highest standards of comfort, reliability and regularity. If we do not do not do this, no one else will- as the comings and goings of many other carriers over the years have demonstrated."

A stronger version of the argument that Aer Lingus was not just about aviation is reported by Share (1986, p.276) from a retirement speech of a company executive in 1985: "there is more to running Aer Lingus than running an airline for profit. I feel that it is an essential badge of our nationality." When Ireland had no transatlantic airline, "for the emigrants streaming westward out of Shannon the foreign aircraft were simply a midtwentieth century version of the nineteenth-century coffin-ships.” The start of an Aer Lingus service gave them "the feeling that they could always come back"

\section{A parliamentary revolt}

The first challenge to Ireland's highly controlled and protectionist aviation policy was posed by Transamerica Airlines which was prosecuted for selling tickets between Ireland and the United States at less than the price approved by the Minister for Communications. The High Court granted the injunction against Transamerica but determined that the Air Transport and Navigation Act, 1965, which gave the Minister power to control air fares, did not apply to travel agents (High Court decision 1984 No 2762, 9 April 1984). The Supreme Court subsequently upheld the appeal of Transamerica Airlines against the High Court injunction restraining the airline from selling tickets for travel between Ireland and the United States at less than the price approved by the Minister. Whether the airline was in breach of the law would have to be determined by trial rather than injunction.

The government introduced the Air Transport Bill, 1984 to Parliament on 27 June 1984 as an emergency measure. The purpose of the Bill was to control the discounting of air fares because a final determination of a legal action against Transamerica might take 12 months and in the meantime powers to control air fares could be severely undermined: "This could lead to considerable instability in the market with discounting and other malpractices emerging on a scale that would undermine approved tariff structures and could have serious implications for airlines generally and Aer Lingus in particular." (Parliamentary Debates, Vol 362, Col. 855).

The emergency legislation failed to secure parliamentary approval. A Bill being stopped on the floor of the House is a rare parliamentary event in Ireland. Since independence, the Irish parliamentary system has had strong party whip controls over parliamentarians and strict party discipline.

The crucial speaker against the Bill was Mr. Desmond O’Malley, a former minister for justice and a former and future minister for industry and commerce. At the time of the aviation debate he had been expelled from the main opposition party, Fianna Fail and was 
thus not subject to that party's whip. He spoke against the Bill citing the harm which high and rapidly rising access fares were causing in the wider Irish economy. Ireland vitally needed lower not higher air fares. The Irish Times report of the debate was headlined “Trying hard not to agree with Dessie”, a tribute to O’Malley's oratory which also earned him the Magill politician of the year award for 1984. The Bill had been introduced by a junior minister because the minister was in Japan on official business. The minister was not present to rally his backbenchers in support of the Bill. Some backbenchers spoke against the Bill in parliament and others did so in party rooms. There was also disquiet on the opposition benches apart from support from the Dublin North constituency which included the Aer Lingus headquarters at Dublin Airport. In the event the agreement of the whips required to facilitate the fast passage of legislation was not forthcoming. The decision not to facilitate the Bill on that day was announced to the House by the opposition chief whip and later three-term Prime Minister (Taoiseach) Mr. Bertie Ahern. When asked by the Speaker to confirm that the Bill could proceed to the Committee Stage the next day, Mr. Ahern replied that

"I know the terminology here is governed by technical reasons but the answer is "no" for the record.

However to overcome the regulations with which we have to comply the answer is "yes"."

(Parliamentary Debates, Col. 910).

This was in fact a "no". The Bill did not go to the Committee Stage the next day and the parliament went into its summer recess.

Ireland might be said to have had its Kennedy hearings on airline deregulation all in a single afternoon while in the US Breyer (1982, p.328) found that "it was no easy matter to overcome the bureaucratic resistance to major policy change in a limited amount of time." O’Malley's oratory and his unique independent position at the time served as a political catalyst for change. His ability to generate cross party support echoes the bipartisan congratulatory letter from President Ford to Senator Kennedy which facilitated regulatory change in US aviation policy (Breyer, 1982, p.339).

\section{The economists' petition against the air transport bill}

The petition was circulated on the eve of the introduction of the Bill to Parliament. It was endorsed by ten economists in the Dublin universities and in financial services. Several of the signatories were government appointees to State company boards and advisory bodies. The petition reads as follows:-

\section{“The Air Transport Bill 1984}

We the undersigned regret the hasty introduction of a Bill designed to limit competition among airlines and travel agents to the obvious detriment of the fare paying public. The attempt to pass this Bill by agreement and without the proper debate which such a measure requires is wholly at variance with public pronouncements on the need to encourage efficiency and lower costs and further lowers public confidence in our legislators.

The speed with which this Bill was introduced contrasts with the lethargic pace adopted in implementing many other economic and social reforms. It would appear that the Government and Opposition care more about the interests of state monopolies than the public as a whole.

We can find no justification for this price increasing legislation in any of the 1982 election manifestos. It is wholly at variance with the commitment in the Programme for Government to "make a determined and sustained attack on the domestic factors which push our inflation rate far beyond the average EEC level”. It flatly contradicts the Fine Gael manifesto commitment to 
increase the powers of the Restrictive Practices Commission to regulate cost increasing actions by domestic monopolies.

Our present economic difficulties stem as much from the lack of debate over legislation concerning publicly owned bodies as from undisciplined fiscal policies. The current Bill continues the steady rise in concern for the interests of public monopolies at the expense of consumers.

(Signed; Brendan Dowling, Colm McCarthy, Robert Kelliher, Tony Garry, Joe Durkan, Sean Barrett, Patrick Geary, John Kennan, Antoin Murphy, Douglas McLernon.)”

The economists' petition against the Air Transport Bill was influential because of the high public profile of the signatories as members of public bodies in economics, finance, tourism, energy, and higher education. In his analysis of the parliamentary processes which led to airline deregulation in the United States Breyer (1982, p.327) states that "Twenty economists criticise CAB” may be interesting, but it is not a story”. In the Ireland of 1984 the petition was a major news story. The Air Transport Bill was now widely acknowledged to be protectionist in favour of one company. The national interest was no longer identified with the national airline interest.

\section{$7 \quad$ The tide turns in favor of deregulation}

Throughout the 1980s, popular dissatisfaction with Irish air fares increased. Departmental control over fares was shown to be weak in cases where increased fares were charged on advance purchase tickets before the fares had approval. The fares were then retrospectively rubber stamped by the Department with no refund for passengers who had paid the unauthorised fares. The Department lacked both information and economic expertise in assessing fare increase applications such as route costings or the proportion of passengers travelling at each fare.

Price increases of 5 to 8 per cent took effect from October 1984. Aer Lingus organised briefings of parliamentarians in that month "in order to improve its image". The Irish Times (2 September 1984) sated that

"The company is concerned about the increasing level of criticism of its policies on air fares, much of which surfaced after the Government tried to rush through the Dail (parliament) the Air Transport Bill to deal with a loophole in earlier legislation controlling air fares. A number of tour operators and economists claimed that the Bill would bestow an unfair advantage on Aer Lingus. The former Fianna Fail Minister, Mr Des O’Malley, also strenuously opposed some of the sections of the Bill, which he claimed were anti-consumer. "Instead of decreasing the cost of access to the country we are introducing legislation to ensure that our already extraordinary high fares are made higher still”, he told the Dail in June last.”

The Aer Lingus briefings of parliamentarians in October 1984 contained the material in Section 4 above. Additional material included the case that the lower per mile cost on London-Belfast than on London-Dublin was due to the former being a domestic route and having a "higher proportion of full fare military and business traffic." The "current BelfastLondon fares are particularly low because of a price war" and British Airways "has stated that the Belfast-London fares are uneconomic". Dismissive views of US deregulation were attributed to “a Massachusetts Institute of Technology study (Taneja, 1983)

showing that fare increases since deregulation have kept up with the general inflation level; that passengers travelling in markets of low to medium density and length of haul have experienced significant increase in fares in real terms; that the greatest benefit of lower real fares occurred in only 5 markets out of 24,000 ; and that only $2.5 \%$ of total passengers in the sample travelled in these 
five markets. The highest increase in real fares was experienced by passengers in $56.5 \%$ of the total markets.” (Aer Lingus Fact Sheet No. 1, October 1984).

Aer Lingus added in December 1984 that this 56.5\% of routes were "routes of a type in terms of distance and traffic density which would include the Dublin-London route" (Sunday Tribune, 19 December 1984)

Fact Sheet No. 2 warned that

"Without regulation, governments would lose the power to intervene in the national interest. In a free market, experience on US domestic flights has shown that there is a danger of higher fares and service cuts on the less dense routes; dumping of surplus capacity at below-cost prices; predatory price wars leading to withdrawal of service or even bankruptcies; below cost selling by large carriers to eliminate weaker competition and peak-skimming which undermines the provision of adequate year-round services on routes where demand is seasonal.”

Fact Sheet No. 3 stated that "Aer Lingus contributes significantly towards the nation's finances; plays a central role in generating tourist earnings and provides a strategic link between Ireland and the rest of the world.” The 500,000 tourists were claimed to generate 32,000 jobs. The Company’s staff paid $£ 29 \mathrm{~m}(€ 37 \mathrm{~m})$ in taxes and spent $£ 14 \mathrm{~m}(€ 18 \mathrm{~m})$ in tourism promotion and "its year round comprehensive service helps to ensure reasonable air fares particularly at off-peak times”.

Fact Sheet No. 4 stated that Aer Lingus carried 2.2m passengers in 1983, of which 432,000 were on charters and 280,000 were on Atlantic services. Direct airline staff was reduced by 960 to 6,577 between 1980 and 1984. It also stated that Aer Lingus was hampered by factors such as high inflation in Ireland, a strong dollar, short sector distances, high seasonality and a small home market. The final fact sheet stated that the airline’s ancillary activities had generated £90m (€114m) profits since 1972 in areas such as hotels and engineering.

The Fact Sheet and related presentations by Aer Lingus echoed objections to the Kennedy Committee hearings raised by the $\mathrm{CAB}$ and the airlines. These included reduced service to smaller communities, increased risk for individual airlines and aircraft manufacturers, loss of labour and airport incomes, increased industry concentration, predatory pricing, loss of network service and reduced safety (Breyer, 1092, p.331).

The Fact Sheet presentations to the parliamentarians conveyed a protectionist view of the airline rather than a wider national perspective. In the high unemployment economy of Ireland at the time government intervention even with a low ratio of benefits to costs was judged superior to market forces in tackling the country's severe economic problems. The fare comparisons proposed by the airline were strongly disputed. Emigration to the United States resumed in the 1980s and public opinion in Ireland was widely aware of the benefits of US airline deregulation. The airline data showed a serious productivity problem in Aer Lingus with 334 passengers per year per staff member in 1984 and 283 in 1980. The contrast in Section 9 below with 11,000 passengers per year per Ryanair staff member in the deregulated market in 2008 is marked.

Public opinion moved against the old Aer Lingus national airline model and did not accept either the gloomy versions of US airline deregulation. Share, in the official history of Aer Lingus celebrating its first fifty years in 1986 stated that "as consumerist and monetarist attitudes became fashionable in the early and mid-1980s, the social role of Aer Lingus came increasingly under scrutiny" (Share, 1986, p. 262). Share also notes a 1981 address by the Chief Executive of Aer Lingus to the National Management Conference which referred to "increasing questioning of the value of state companies relevance, partly because of a reaction against the increasing role of central government in all our affairs ... 
the charge is that state sponsored industry may have become irrelevant to today's needs and even parasitical in nature." Share states that "this theme was pursued by popular advocates of monetarist economics. In the transport sector in particular, Sean D. Barrett questioned the role of the State in the provision of internal surface transport whilst conducting a sustained campaign in favour of de-regulation of air fares with particular reference to Irish Sea routes” (Share, 1986, p.261).

The aviation minister, Jim Mitchell and the Prime Minister (Taoiseach), Garret FitzGerald, a former economist at Aer Lingus, moved away from the protectionism of the Air Transport Bill in the last quarter of 1984. On 2 October, the Minister notified Aer Lingus that proposed fare increases from Dublin and Cork to Amsterdam and Brussels of 16-18\% were "more than twice too high". An appeal by Aer Lingus was turned down on 28 October. (Minister's press statement, 13 November).

The controversy about these fares attracted front page and lead story status in the leading national newspapers as in the following example from the Irish Independent on November 27, 1984:

"Deregulation really took off in America after Jimmy Carter appointed Professor Alfred Kahn to be President of the Civil Aeronautics Board. He made a bonfire of the red tape and costly regulations and opened the airways to many who could not usually afford to fly. But his ideas did not catch on in Europe, where governments are jealous of their rights and airspace.”

With public opinion now favoring deregulation and the government taking a stricter line on fare approvals the next vital step was to liberalise market entry. The first airline to avail of the more liberal approach to aviation was Ryanair, established in 1985, by the family of Dr. Tony Ryan, then head of the aircraft leasing firm, Guinness Peat Aviation. At that time only the United Kingdom and the Netherlands espoused liberal aviation policies and Ireland's change from the traditional European state airline model to the open market was important. More competitive aviation in Europe was also supported by the Irish EU Competition Commissioner Peter Sutherland, later a director of Delta Airlines.

On February 5, 1985 the Irish Times stated that the government would amend the Air Transport Bill "to provide for more competition between travel agents and airlines". The chairman of the main government party, Fine Gael, stated that the parliamentary party "had been given an assurance that the legislation was not anti-consumer and was not a benefit Bill for Aer Lingus”.

On June 15, 1985 just under a year after the Air Transport Bill was refused emergency passage through parliament Ryanair started on the Waterford-Gatwick route. The start-up airline operated the route with a fifteen seat Bandirante aircraft and carried 15,000 passengers in its first year on the route. Public opinion wanted something far more radical than a small route with a fifteen seat aircraft.

The Government of Ireland (2005, p.71) White Paper on Tourism noted that "there has been a 50 per cent drop in the number of visitors by air from Britain between 1975 and 1983. The Government are examining what steps can be taken to increase the tourist traffic on air routes to and from the UK." Tourism to Ireland had been stagnant at 2 million visitors a year for two decades. The sector demanded reform and supported the consumer and economist movement for reform. The government then decided to introduce competition between Dublin and London-Luton. Ryanair commenced the route in May 1986. The results exceeded all expectations. Irish, and indeed, European, aviation would never be the same again.

In his assessment of the US policy change in aviation, Levine states that "deregulation succeeded against industry opposition because it was supported by a coalition of assorted 
interests: consumer groups, academics who were able to provide concrete examples of lower fares with less regulation, a public disgusted with scandals, charismatic individual spokespersons, and politicians looking for an anti-inflation or pro-market issue. All these interests created a media blizzard that lasted for several years” (Levine, 2007, p.235). The main consumer group in favor of deregulation in Ireland was the Air Transport Users Committee which operated within chambers of commerce and which was strongly critical of the high fares charged in business class. Small and medium enterprises supported change whereas larger industry typically did not. Others who travelled ahead of the curtain in business class included government ministers and senior civil servants and supported the status quo. Aviation journalists and travel correspondents generally enjoyed favorable treatment from the legacy airlines and supported the status quo. Most other journalists, in particular economics writers, supported deregulation and created a media blizzard that persists two decades later. Fare data on low fares charged by European charter airlines, routes within California, and the Belfast-London route were highly influential in a small open economy within the EU and with strong investment and ethnic links with the US. Public opinion was disturbed by the general underperformance of the Irish economy in the early 1980s, a period in which both the national debt and unemployment doubled and wanted a lower cost of getting on and off an outer offshore island. The charisma was provided first by Dr. Tony Ryan, founder of Ryanair and latterly by Michael O’Leary, chief executive.

It is interesting to contrast the Irish experience with the economic theory of regulation following the example of Peltzman (1989) in his examination of US aviation after a decade of deregulation. The economic theory of regulation is based on the need to correct market failure. "The ingenuity of economists ensures that the list of potential sources of market failure will never be complete. But in the early 1960s the most popular culprit was natural monopoly followed at a distance by externalities." Government intervention to achieve the correction generates economic rents and the intervention is likely to be dominated by producers at the expense of less-concentrated and less-organised groups such as consumers, a point emphasised by Stigler. Regulatory policy will seek to preserve a politically optimal distribution of rents across the dominant coalition of producers and some subsets of consumers. The regulatory process involves deadweight losses. Policies which reduce the total wealth distribution will be avoided because they reduce the political payoff from regulation.

The application of the economic theory of regulation to Irish airline deregulation yields several interesting policy insights. There was no market failure and no attempt to prove market failure. The policy was based instead on market prevention even before Aer Lingus was established. Regulation was dominated by producers and substantial rents were enjoyed by the management and staff of the protected airline.

The collapse of Irish aviation regulation virtually on a single afternoon indicates that the rents generated by regulation were enjoyed by Aer Lingus alone and that there were no significant subsets of consumers receiving rents from regulation. There was no evidence of cost-increasing service rivalry as noted by Peltzman but a high fare no frills service. The collapse also indicates that there were serious deadweight losses from regulation because it raised access costs and reduce travel to and from an outer offshore island.

Aer Lingus did not produce any evidence of "enforced provision of service to selected groups at especially low, often below-cost prices subsidised out of potential producer rents generated elsewhere in the regulated industry" (Peltzman, 1989, pp. 8-9). Public opinion in 
Ireland was virtually unanimous that air fares were too high in all markets. No evidence was produced of enforced provision of service in return for exemption from new market entry.

The vast majority of Irish airline passengers and citizens as a whole had lost faith in airline regulation in 1984. They communicated this to a populist political system based on multi-member constituencies and a proportional representation voting system. The organisational costs associated in the literature with consumers as less organised and lessconcentrated than producers were small because little organisation was needed due to the overwhelming pressure of public opinion in favour of deregulation.

Political entrepreneurship was shown by Mr. O'Malley in the Irish case and the commercial entrepreneurship of Ryanair was vital in achieving policy change in Ireland and later becoming the biggest airline in Europe in terms of passenger numbers.

Two further points from Peltzman illuminate a comparison of US and Irish airline deregulation. These are that "the entrepreneurial influence of Alfred Kahn and Elizabeth Bailey cannot be overstated" and that the "demonstration effect" is important (Peltzman, 1989, p.59). The economists who signed the policy petition in Section 6 above were policy entrepreneurs in the Kahn-Bailey tradition and in a strong Irish tradition described in Section 12 below. They had been increasingly pressed into service because of widespread policy failure in both political and administrative circles in Ireland in the 1970s and 1980s and became public figures in that context.

The demonstration effect was provided by the success of deregulation in the United States and the determination of Transamerica to resist the regulation that the Department of Transport had sought to impose on it in Section 2 above. The court successes of Transamerica were unprecedented in the conduct of any European airline serving the Irish market. That legal success precipitated the emergency legislation whose rejection led to deregulation in Ireland ahead of the rest of Europe. In turn that demonstration effect led to Ryanair modelling itself on Southwest rather than on any airline based in the still highly regulated European market. Ryanair then had first mover advantage in the single European aviation market. The demonstration effect of US airline deregulation and the need to deregulate in Europe were more keenly felt than in Ireland than elsewhere in Europe.

\section{The most spectacular airline deregulations?}

Deregulation of Irish air routes took place in four phases. The first was deregulation between Dublin and London. This was followed by deregulation on UK provincial routes outside London and deregulation on routes to mainland Europe. The final major deregulation in March 2008 was open skies with the USA, part of the overall EU/USA open skies agreement.

On the Dublin-London route's deregulation day, May 23, 1986, the unrestricted fare was reduced from £IR 208 (€264) on Aer Lingus and British Airways to £IR94.99Ir (€121) on Ryanair, a fall of 54.2\%. In response, Aer Lingus introduced a London Business Bonus hotel voucher worth up to EIR 115, a 55\% discount on the EIR208 fare. In addition, the 28 day APEX fare was reduced to £IR63, a 33\% reduction. The 14-day APEX fare was reduced to EIR77, a 35\% reduction; In addition, late saver standby fare of £IR69 and a special saver fare of £IR75 were introduced. A super budget fare of £IR123, a three day business fare, was introduced at a $41 \%$ reduction on the £IR208 fare. 
In the first full year of deregulation, 1987, passenger numbers between Dublin and London were $65 \%$ more than in 1985, the last full year before deregulation. The marked contrast between the stagnation on the route for five years before deregulation with high fare increases, as shown in Table 3 above, with the dynamic impact of large passenger volume increases and fare reductions in shown in Table 4.

\begin{tabular}{|l|l|l|}
\hline Change (\%) & Passenger Numbers & Fares \\
\hline Five years pre-deregulation 1980/5 & +2.8 & +72.5 \\
\hline First full year of deregulation 1987 & +64.9 & -54.2 \\
\hline
\end{tabular}

Table 4: Regulation and deregulation contrasted on the Dublin-London route

Source: Barrett (1990)

Table 5 shows the month on month increase in passenger numbers in 1987 over 1985, the last full year of pre-deregulation policies. The monthly increases ranged from $34.2 \%$ in March to $91.7 \%$ in August, the main month in Irish tourism. The large increase in travel in the peak month of August in the competitive market indicates that before deregulation the incumbents used their monopolistic power to reduce supply thus increasing their average yield per passenger. The contrast between the two years indicates that the pre-deregulation policy of a national airline promoting Ireland as a destination was markedly inferior to tourism promotion by lowering fares in a deregulated market.

The August 1987 increase of almost 98,000 passengers was evenly split between the new entrants and the incumbents. Deregulation had a remarkable stimulatory impact on the output of the incumbents whose growth of only $2.8 \%$ over the previous five years was transformed in the competitive market to a half share in a $91.7 \%$ growth in the peak month of first full year of deregulation. Deregulation brought to the Dublin-London route both the dynamism of new market entry and a competitive response from the previously lethargic incumbents.

The second phase of the deregulation of Irish air routes was the deregulation of the Ireland-United Kingdom routes outside London and took place in 1993/4, some seven years after the Dublin-London deregulation. Until deregulation occurred, Aer Lingus as the incumbent continued to charge high fares on these routes. Potential market entry did not secure fare reductions but actual market entry had dramatic impacts. Ryanair entered the Dublin-Birmingham route in November 1993. It became the market leader in December 1993 with 53\% of the market, which was then 67\% greater than in the previous December. It entered the Dublin-Manchester route in May 1994 and became the market leader in June with 55\% of the market, which was 56\% greater than in June 1993. It also entered the Dublin-Glasgow route in May 1994 and became the market leader in June in a market which grew by $112 \%$ compared to June 1993 . The market shares in the deregulated market in June 1994 were Ryanair 46\%, Aer Lingus 41\% and Manx 13\%.

The response of Aer Lingus in this phase of deregulation was to concentrate on the Dublin-London route response to Ryanair rather than prepare for competition elsewhere on its Ireland/UK network. Fare reductions on the other Ireland/UK routes did not occur until actual market entry took place. Accordingly, the superiority of actual over potential competitors (Kahn, 1987), is clearly demonstrated by the Ireland/UK deregulation. 


\begin{tabular}{|l|l|l|l|}
\hline \multicolumn{3}{|c|}{ Passengers ('000s) } \\
\hline Month & $\mathbf{1 9 8 5}$ & $\mathbf{1 9 8 7}$ & Increase (\%) \\
\hline January & 63.2 & 87.4 & 38.2 \\
\hline February & 59.4 & 89.0 & 49.9 \\
\hline March & 80.8 & 108.4 & 34.2 \\
\hline April & 76.4 & 124.0 & 62.3 \\
\hline May & 82.0 & 118.4 & 44.4 \\
\hline June & 92.3 & 147.0 & 59.3 \\
\hline July & 97.2 & 177.6 & 82.7 \\
\hline August & 106.7 & 204.5 & 91.7 \\
\hline September & 93.3 & 168.7 & 80.8 \\
\hline October & 85.3 & 157.6 & 84.7 \\
\hline November & 75.8 & 122.3 & 61.4 \\
\hline December & 78.9 & 130.7 & 65.7 \\
\hline Year & 991.7 & 1635.5 & 64.9 \\
\hline
\end{tabular}

Table 5: Dublin-London passenger numbers under regulation in 1985 and deregulation in 1987

Source: Barrett (1990).

The third phase of Irish deregulation was on routes to mainland Europe. Fares on these routes were high and surface transport competition weak due to long sea journey times. For example, Byrne (2004) notes that when his airline, Cityjet, entered the Dublin-Brussels route in 1995 the fare was £IR $600 € 762$ ), or €1053 at 2006 prices. The Aer Lingus prospectus on its privatisation in 2006 showed an average short-haul fare of $€ 86.49$ in the first half of 2006. This return fare of $€ 172.98$ per return journey is $18.4 \%$ of the prederegulation fare and a reduction of $81.6 \%$ on the pre-deregulation fare. In the case of passengers who chose Ryanair in the deregulated market the average fare in 2006 was $€ 40.70$ one way and a reduction of $92.3 \%$ on the pre-deregulation fare.

A return trip to Brussels from Dublin in 2006 on Ryanair was thus $7.7 \%$ of the prederegulation fare. Fares to other mainland points were even higher than on DublinBrussels. For example in 1987, the Dublin-Rome fare of $€ 904$ was $78 \%$ more than the Dublin-Brussels fare of $€ 508$. The Ireland/mainland Europe routes also required actual market entry by new airlines in order to secure lower air fares. There were twelve points in mainland Europe served from Dublin, Cork and Shannon in 1987. In the summer of 2007, there were 101 routes to mainland Europe from Dublin, 21 from Shannon, and 18 from Cork (Chambers Ireland, 2007).

The fourth phase of Irish airline deregulation came into effect in March 2008. This is the Open Skies agreement between the EU and the USA. The EU Commissioner for Transport estimates that overall EU/USA traffic will increase by $8 \%$ in 2008 with increases from Heathrow of $20 \%$, Spain $15 \%$ and Ireland of $23 \%$. The number of Ireland/USA flights will increase from 119 to 146 per week. Three new routes will open between Ireland and the USA under open skies, to Orlando, Washington and San Francisco, bringing to ten the number of routes between the two countries (Barrett, 2008). 
Unlike the Ireland/UK and mainland Europe deregulations, potential market entry under deregulation has influenced conduct in the Ireland/USA market. Aer Lingus has reduced its average fare on the Atlantic from €327.8 in 2001 to $€ 240.8$ in 2005, a reduction of $35 \%$ in real terms.

The optimism concerning Ireland's expected traffic increase under open skies on US routes is based on the reduction of two sets of impediments to efficient travel between the two countries before open skies. These are the Shannon stopover and the lack of direct routes to Ireland from US regions. The Shannon stop requirement imposed extra burdens on airlines and passengers by requiring them to stop both in Dublin and Shannon which are a mere 112 air miles apart. The lack of direct service between some US regions and Ireland routed passengers over hubs such as Heathrow. Trips thus became cumbersome as passengers flew over Ireland, hubbed at Heathrow and then flew back to Ireland. Direct service from more US points to Ireland is will save journey times, reduce lost baggage, and reduce the costs of hubbing such as multiple security, customs and immigration delays. In the words of Kahn (2005), "the consumer benefits have taken the form not only of huge monetary savings but also more convenient access to a greater number of origins and destinations.” The EU/USA open skies agreement also marks a vital tilting of the balance in world aviation from the previous restrictive bilaterals towards open skies and open aviation area agreements. In the UK case after open skies with the USA in 2008, it is estimated that over $90 \%$ of international aviation from Britain will be under open skies or open aviation area agreements (Civil Aviation Authority, 2007).

The volume changes in Irish aviation since deregulation are also striking. The protected single Irish airline in 1983/4 had 2.2m passengers. The four Irish competing airlines in 2008 will have $72 \mathrm{~m}$ passengers, an increase of $3,172 \%$ in the number of passengers carried. The large productivity increases in the sector are examined in Section 9 below.

The passenger volume increases and price reductions following Irish airline deregulation have surprised even the strongest advocates of deregulation, including the present writer. The high fares and low volumes before deregulation indicate he draconian extent of restrictions on competition in the era of regulatory capture. Fares declined after deregulation in part because they had such a distance to fall in the first instance. Fares also declined because Ryanair proved to be a spectacular new market entrant, as indicated in Section 9 below. Fares have also declined because Aer Lingus has raised its productivity in terms of passengers per staff member per year to significantly above the European legacy airline average of some 1,000 passengers per staff member per year. Irish airline deregulation has combined the dynamism of new market entry and the competitive response of the incumbent.

Doganis (2006, p.35) states that

"The most dramatic impact of liberalisation was evident on the London- Dublin route. In May 1986 a new airline, Ryanair, launched a Dublin service from Luton, an airport $50 \mathrm{~km}$ (30 miles) north of London, offering very low unrestricted fares. Average passenger yields dropped by a third in three years. There had been very little growth in passenger traffic between London and Dublin between 1980 and 1985, but it doubled in the next three years to 1988."

The reductions of $82 \%$ and $92 \%$ on the pre-deregulation Dublin-Brussels fare are mirrored throughout the large network of direct services between Ireland and mainland Europe developed at low fares since deregulation.

Breyer and Stewart (1992, p.707) estimate that in the first decade of deregulation in the US "fares in 99 percent of the system had fallen by nearly 30 per cent since 1978 and 
passenger miles flown increased from 163 billion in 1975 to over 400 billion in 1987”. The award of gold, silver and bronze medals for airline deregulation is a task for others but the Irish case study is spectacular by any standards.

\section{Economic rent, protectionism, and Ryanair's market entry}

The economic rent from protectionism in Irish aviation and regulatory capture of policy by Aer Lingus as the incumbent monopolist was reflected in low productivity. Aer Lingus, according to its Fact Sheet No. 3, in Section 7 above, reduced its direct airline staff by 960 between 1980 and 1984 to 6,577. Passenger numbers were $2.1 \mathrm{~m}$ in 1980/1 and 2.2m in $1984 / 5$. The ratio of passengers to staff was 282 in 1980/1 and 334 in 1984/5, or 0.77 passengers per day per staff member increasing to 0.92. By contrast in the deregulated market, Aer Lingus reduced its staff to 3,500 and increased its passenger numbers to $9 \mathrm{~m}$ thus increasing its productivity to 2,571 passengers per staff member. This is 7 passengers per day per staff member and a 7.7 fold increase compared to the 1984/85 figure. The stimulus of deregulation in raising the productivity of Aer Lingus is a major benefit from market deregulation.

In addition to lowering productivity in the protected airlines, a policy of preventing competition in aviation might be expected to increase the incomes of their staff. Barrett (1997) compared the ratio of average airline staff remuneration to GNP per head for fourteen European countries, the United States and Canada in 1984. On average, airline staff earned 2.56 times the GNP per head. The airlines which exceeded this ratio by over $50 \%$ were TAP, Aer Lingus, and Iberia with pay respectively at 6.0, 4.0 and 3.8 times GNP per head. Aer Lingus staff were the second most successful in converting the economic rent of protectionism into high relative incomes compared to the rest of the economy. The contrast with British Midland, then one of the few privately owned operators of scheduled services in Europe but with little scope for rent-seeking, is remarkable. British Midland output per staff member was 54\% higher than in Aer Lingus but remuneration was 31\% lower. Labour costs per passenger at British Midland were therefore only $45 \%$ of those at Aer Lingus.

The major stimulus to the Irish aviation sector from deregulation has been from new market entry, in particular the remarkable success of Ryanair. The 2008 estimated passenger numbers on Ryanair, 58m, with a staff of 5,300, means 11,000 passengers per staff member. This is 4.3 times the level at Aer Lingus and 33 times the pre-deregulation productivity at the heavily protected Aer Lingus.

Ryanair in 2008 will carry 5.5 times more passengers than Aer Lingus. It is the first new entrant airline to eclipse its national airline. It is also the first pan-European airline, with some $80 \%$ of its passengers carried on journeys to and from countries other than its home base in Ireland. Ryanair also redefined the European airline product, bypassed slotconstrained hubs in favour of secondary low-cost airports, and abolished ticket sales through travel agents. These factors were noted by Levine (1987) in his seminal paper on airline competition in deregulated markets. Levine (1987, p.408) also lists as "interesting deviations from perfect competition or perfect contestability", factors such as "mergers, vertical integration, hub domination, complex fare structures and frequent flyer programmes, the role of travel agents, the use made of computer reservation systems, the use of airport slots and gates, predation and new entrant fatalities”. 
The Ryanair decision to use secondary airports allowed it to negotiate lower landing charges and twenty-five minute turnaround times and to bypass several of the deviations cited by Levine. As a point-to-point airline, it did not require access to hub airports for interlining and as a budget airline it did not wish to either purchase slots or pay high charges at hub airports. Since Europe has many airports in a relatively concentrated area with high population density, Ryanair found a ready supply of underutilised airports eager to do business. Passengers were also willing to transfer to the new services at these airports. The advantages cited by them and Ryanair were less waiting and walking times, less airport congestion and confusion, fewer lost bags, and cheaper car parking. Morrison and Winston (1989, p.66) also note the benefit of direct point-to-point service. "We find air travellers have a high value of time, nearly \$35 an hour and an even higher value of transfer time. The latter value reflects the disutility to air travellers of the time spent walking through terminals and waiting at their departure gate to make a connection.” The capacity at its underused airports allowed Ryanair to rapidly expand its service on these routes without encountering slot constraints and to rapidly increase its passenger numbers from exceeding 1 million passengers for the first time in 1993 to 58 million in 2008. As Bailey and Panzar note "the chief sunk cost in aviation is the cost of airport plant runways, towers, and ground facilities” (Bailey and Panzar, 1981, p.132). Ryanair significantly increased the efficiency of this infrastructure by utilizing the sunk investments by cities, regional authorities and air forces in airports which were anxious to increase their use. Problems of hub airport dominance, slots and gates were avoided by the use of secondary airports thus improving the efficiency of airport capacity utilisation. Hub airports in turn have responded by offering better terms to Ryanair and easyJet in the expectation that low-cost airlines generate higher passenger volumes such as the enticements by Brussels airport to easyJet in competition with Ryanair at Charleroi.

In 2008, the UK Competition Commission proposed that the market dominance of the British Airports Authority should be reduced by divestiture of Stansted and Gatwick in the London area and of either Glasgow or Edinburgh in central Scotland. In Ireland, the national airport agency, Aer Rianta/Dublin Airport Authority, is to lose control over Cork and Shannon airports. A policy of competing terminals at Dublin Airport attracted some fifteen expressions of interest by aviation, financial and property interests but was abandoned in 2005 after three years because of opposition from airport management and trade unions. Bailey (1989, p.115) cites a case at Pittsburgh involving US Air and warns that "such virtual ownership of airports by carriers limits competition".

While Ryanair devised a policy to move to Europe's secondary airports in order to use generally available spare capacity, the decision to cease using travel agents resulted from the development of the Internet. Travel agents had in any case an incentive to route passengers through high fare rather than low fare airlines and in doing so to favour airlines offering agents increased override commissions on sales. Kahn (1989, p.116) also notes that "airlines have engaged in such strenuous efforts to acquire computer reservation systems (CRSs) and promote their adoption by travel agents”. Travel agents routed customers through the dominant CRS in their region. The Irish case study supports Kahn in this regard rather than Morrison and Winston's (1989, p.68) finding that "the ownership of a CRS had an insignificant effect on carrier choice”. Travel agents as barriers to contestability in a deregulated market were undermined by the development of the Internet and Ryanair was a leader in its adoption. The Internet deals with the problem of complex fare structures by disintermediation. The passenger engages in a virtual perfect market by 
downloading price information from several airlines and choosing the best price-service trade off.

A further obstacle to the contestability of the deregulated aviation market noted by Levine was frequent flyer programs. These encouraged passengers to concentrate their trips on one airline in order to qualify for more rewards such as free trips and discounts. Frequent flyer programs were thus a barrier to entry by new start-up airlines. Ryanair abolished its frequent flyer program in order to focus on offering the lowest price. The abolition of its frequent flyer program reduced Ryanair's administration costs and check-in times.

There are items on the Levine list which persist in 2008 however, such as mergers, predation and barriers to market entry and exit. On mergers, Europe is willing to allow mergers in the consolidation of legacy airlines in three broad groups, Air France-KLM, British Airways-Iberia, and Lufthansa-Swiss-SAS but in the low cost sector has disallowed a Ryanair takeover of Aer Lingus. Morrison and Winston's assessment of six mergers in the US was evenly split between three welfare enhancing and three welfare reducing mergers.

Market exit happened in the cases of Sabena and Swissair but Alitalia remains heavily subsidised. Predation remains difficult to distinguish from pricing to fill empty seats. The number of scheduled airlines in Europe increased from 77 in 1992 to 139 in 2000 and market exit by naïve entrants is inevitable in an industry where the legacy airlines have restructured and where new entrants face low cost carriers with costs among the lowest in the world. Market assessments in mid-2008 indicated that up to fifty European airlines were at risk due to high fuel prices at that time.

Levine's (2007, p.232) later assessment is that "in his world, the choice is never between imperfect markets and perfect regulation or between imperfect regulation and perfect markets. The choice is between imperfect markets and imperfect regulation.” The broad consensus in favour of the benefits of airline deregulation prevails. Schemes of "reregulation" are unlikely to succeed either in the US or in Europe. European aviation may be said in 2008 to exhibit greater contestability under deregulation than US aviation under deregulation because of factors such as less congestion at secondary airports and their use by low cost airlines, and less reliance on travel agents, CRSs and frequent flyer programmes in the retailing of airline tickets

Returning to the changes following deregulation in Europe, Table 6 shows the airline product changes introduced by Ryanair. The average fare per passenger in the year to September 2007 was $€ 49$ and the net margin was 18\%. This margin compares with $6 \%$ on Aer Lingus, easyJet, and Southwest, 4\% on Lufthansa and 3\% on British Airways. Davy (2006b, Table 12) estimated that the unit cost per available seat kilometre on Ryanair was 4.0 cents (European). This compared with 5.9 cents on easyJet, 7.8 on British Airways, 8.5 on Continental, 8.8 on American, 9.0 on US Airways and 9.7 on Delta. The Ryanair low cost/low fare model is based on high labour productivity within the airline, the use of secondary airports, the use of economic leverage to secure volume discounts from input suppliers, Internet sales, and the product features listed in Table 6.

The ultimate test of the Ryanair low cost product is its market acceptability Davy (2006a) found that $83.17 \%$ of Ryanair passengers had flown with the airline before. Just fewer than $4 \%$ of passengers rated their flight experience as poor or very poor. Fewer than $6 \%$ of Ryanair passengers would pay more for an extra legroom seat. 1993 was the first year in which Ryanair had more than 1 million passengers and the number has steadily 
increased to 55 million in 2008. While there may be some residual nostalgia for the old era of full service airlines in Europe among those who then travelled ahead of the curtain, which partitioned aircraft between business and economy class, few passengers are willing to trade off higher fares for such a service. On the Ireland/United Kingdom routes, the longest standing deregulation in Europe, with over 12 million passengers in 2006 under $1 \%$ chose the sole remaining full service airline, Cityjet, operating to London City airport. British Airways withdrew from the Irish market in order to concentrate on longer haul routes with higher yields. Aer Lingus and British Midland dropped their business class in order to compete with Ryanair, the low cost market leader on Ireland/UK routes. The UK Civil Aviation Authority (2006) notes that in contrast to the rapid growth of low cost airlines in Europe, full service airlines have had no increase in their passenger numbers since 2000. The Ryanair proportion of passengers on business trips, $23.15 \%$, exceeds the proportion of business trips on all access transport to Ireland at $14 \%$ and on all foreign travel trips by persons resident in Ireland, at $12 \%$. The business sector has chosen the low cost airline product rather than the traditional airline business class product.

\begin{tabular}{|l|}
\hline Point-to-point travel - a simpler product- cheaper to provide \\
\hline Highest productivity staff \\
\hline Secondary airports served - less congestion for planes and passengers \\
\hline Twenty-five minute turnaround times at airports \\
\hline Sales through travel agents and retail sales offices deleted; ticketless travel \\
\hline $\begin{array}{l}\text { Customer service items deleted: sweets, newspapers, food and beverage, seat } \\
\text { allocation, business class, airport lounges, frequent flyer programme }\end{array}$ \\
\hline $\begin{array}{l}\text { Customer benefits: lower fares, more routes (627 in 2008), improved punctuality, } \\
\text { fewer lost bags }\end{array}$
\end{tabular}

Table 6: The Ryanair product features

Source: Barrett (2004)

The corporate culture of Ryanair, based on a new product type, a competitive market, and a management and staff not inculcated with the corporate culture of Europe's colluding national airlines, avoids the distressed state airline syndrome described by Doganis in Table 2 above.

Competing airlines have in turn placed competitive pressures on services at airports leading to competition at and between airports. Since Europe has one airport per million people, there is huge scope to develop services at airports overlooked in the traditional national airline concentration on national hubs. Regional airports have been major beneficiaries of service from low cost airlines in Europe, including the development of seven new airports on the Irish Atlantic coast. This scenic region had only two routes to London before deregulation from Cork and Shannon to Heathrow. In 2007, traffic was 2.7 times the pre-deregulation level with almost three quarters of it on routes and airports not served before deregulation (Barrett, 2007). 


\section{The dynamic impacts of Irish airline deregulation on transport and the wider economy}

The protection afforded to Aer Lingus before deregulation was similar to tariff and quota protection in international trade with revenue transfer to the protected company rather than to the exchequer. Tariffs and quotas on access air transport are especially ill-advised in an outer offshore island economy such as Ireland with a small home market. The removal of these tariffs and quotas in mid-1986 was therefore expected by proponents of deregulation to have significant impacts on the wider Irish economy. In 1994, the Government of Ireland (1994) Green Paper on Aviation Policy estimated that airline deregulation had generated a $60 \%$ increase in visitor numbers, additional tourism earnings of $€ 711 \mathrm{~m}$ and 25,000 additional jobs in tourism over the years 1987-1993. Tourist numbers were static at 2 million visitors a year for twenty years before deregulation but have since increased to over 7 million. In addition, the volume of outward business travel increased by $50 \%$. The overall impact of deregulation was to increase the competitiveness of the Irish economy. The sea carriers' cartel between Ireland and Britain ended as a result of the ending of the air cartel. Sea fares fell by 40\% in real terms between 1987 and 1995.

The OECD (2001) stated that airline deregulation "provided a clear demonstration of the potential benefits of competition to all consumers, having a significant effect on public opinion”. Trucking for hire was deregulated in 1988, having been subject to strict quantity licensing since 1933 as part of a policy to protect railways from road competition. A professional independent haulage sector developed under deregulation and increased its market share from $11 \%$ in 1964 to $71 \%$ in 2006 while the share carried by industry "own account” and railways declined.

Taxis were deregulated by a High Court decision, upheld in judicial review, in 2000. The economic basis of the verdicts both in the court case and the judicial review is the right of persons to enter a trade or profession for which they had the necessary skill and training and the right of the public to the services of such persons. The scarcity value of licences, based on the success of incumbent licence holders declined from $€ 130,000$, payable to an incumbent holder to a $€ 5,000$ fee payable to the local authority. The number of taxis increased from 3,913 on the eve of deregulation in 2000 to 11,630 in 2002 and 16,429 in 2006.

Two court decisions in 2008 continued the emphasis on deregulation. The High Court refused to grant an injunction to Dublin City Council restricting commercial garbage collection by competing operators. The Supreme Court ruled against a requirement in the health insurance market, that BUPA, a new entrant, should make risk equalisation payments to VHI, a state company and previous monopoly, in order to compensate the latter for its older membership.

While Ireland maintains a rigid bus licensing regime, instituted in 1932 to protect the railways, certain intercity routes have been deregulated in recent years. Barrett (2004) found that on an index of 100, fares on the contested Dublin-Galway route with three competing companies are lower than on routes than where the state bus company faced two competitors (index 133), and much lower on uncontested routes (index of 222). Competition on Dublin-Belfast increased frequency from 7 to 39 services per day in each direction and reduced the fare from $€ 19$ to $€ 12$. Competition between Dublin and Cork reduced the fare from $€ 20.50$ to $€ 7$ and frequency increased from 6 to 14 . There is no general policy of permitting market entry however, and new entrants are excluded from the 
investment grants and operating subsidies which the State as market regulator pays to the state-owned bus companies. Goodbody Economic Consultants (2005) found that the private sector bus fleet in 2003 had passenger receipts which were $77 \%$ more than the state Dublin bus fleet, $41 \%$ more than the state's national Bus Eireann fleet and 124\% more than the state railways. Severe restrictions on the ability of the private sector to operate scheduled services on equal terms with the state companies are currently under investigation by the EU directorate for the internal market and competition.

Competition between airports will be facilitated by the break-up of the state airports group Aer Rianta into separate airports at Dublin, Cork and Shannon in 2008/9. A tendering process for a competing independent terminal at Dublin, which attracted some fifteen entrants, was cancelled in 2005 with the state declaring itself the winner. Competition between terminals was opposed by the incumbent airport authority.

In the wider economy, the demythologising of Ireland's national airline, the dismantling of its protections from competition and its eventual privatisation in 2006 symbolised a profound change in Irish economic policy. The market, rather than the state, became the centre of economic policy. Ireland changed from a high tax and high government borrowing and debt economy to a low tax market economy. Airline deregulation thus paved the way for the wider policy change which led to the Celtic Tiger growth era. Far from being an engine of growth, the experience with airline deregulation has demonstrated that excessive state intervention in the economy is a cause of low productivity, high prices and intervention against the consumer and wider national interest. Table 7 summarises these revolutionary changes in Irish economic policy, which were led by aviation deregulation.

\begin{tabular}{|l|l|l|l|}
\hline & $\mathbf{1 9 8 6}$ & $\mathbf{2 0 0 6}$ & Index (1986=100) \\
\hline Employment (million) & 1.1 & 2.1 & 182 \\
\hline Unemployment (\%) & 17.4 & 4.4 & 25 \\
\hline $\begin{array}{l}\text { Percentage of total employees in } \\
\text { state companies }\end{array}$ & 8 & 2 & 25 \\
\hline GNP per head/EU average (\%) & 60 & 110 & 183 \\
\hline Government spending/GDP (\%) & 53 & 27 & 51 \\
\hline Public debt/GDP (\%) & 131 & 28 & 21 \\
\hline Corporate tax rate (\%) & 50 & 12.5 & 25 \\
\hline Personal tax rates (\%) $*$ & $35 / 60$ & $20 / 42$ & $57 / 70$ \\
\hline Exports/GDP (\%) & 56 & 78 & 139 \\
\hline Overseas visitors (m) & 2 & 7 & 350 \\
\hline
\end{tabular}

*The standard income tax rate was reduced from $35 \%$ to $20 \%$ and the higher rate from $60 \%$ to $42 \%$.

\section{Table 7: The transformation of the Irish economy post airline reregulation}

Source: Barrett (2006) 


\section{Alfred Kahn's successful export of deregulation}

The stunning success of airline deregulation in Ireland indicates a highly successful policy export from the United States to Europe. Opposition to airline deregulation in Ireland was led by the national airline which had a long history of regulatory capture of weak transport regulators. The Irish case of regulatory capture was more pronounced than elsewhere in Europe and the policy change in 1984/6 was therefore more dramatic. Airline opposition to deregulation because fares would not fall, Aer Lingus staff productivity was already high, thin routes would not be served and off-peak services would be withdrawn, proved to be exercises in rent seeking (Bailey and Williams, 1988).

Kahn (1987), on the other hand, accurately predicted results of Irish airline deregulation. Speaking in Chicago in December 1987 on a decade of airline deregulation in the United States he stated that, "The last ten years have fully vindicated our expectations that deregulation would bring lower fares, a structure of fares on average in closer conformity with the structure of costs, an increased range of price/quality options, and great improvements in efficiency- made possible by the abandonment of regulatory restrictions and compelled by the greatly increased intensity of competition - all this along with a 35 percent or so decline in accident rates.” Kahn's (1991) later prescription also stands vindicated. “... genuinely open markets, with a large number of actual and genuinely potential competitors, are better than government second-guessing of competitive pricing responses.” Kahn's (1987) view that “ a competitor in the market is worth six potential competitors in the bush" is also supported by the delay in achieving fare reductions on Ireland routes to provincial UK and mainland European routes until actual market entry by Ryanair.

Kahn (2004) cites the Morrison and Winston estimates of benefits worth over $€ 20$ billion a year from US deregulation primarily in the form of lower fares and vast increases in the availability of one-stop service between hundreds of cities. Ireland has replicated both large fare cuts and large increases in the number of new routes served direct rather than over hubs. Ryanair and Aer Lingus are both point-to-point airlines.

Kahn's (2005, p.4) conclusion that “competition in the unregulated market has proved to the satisfaction of the carriers that most travellers are willing to sacrifice comfort for lower fares" also describes the Irish case. Kahn's (2005, p.5) reference to the need for "major give-backs of the extraordinarily inflated wage costs achieved by the industry's powerful unions" in the US also applies in Ireland. The give-backs sought in the reform of Aer Lingus have raised its productivity to a level above the average of the Association of European Airlines but still significantly below that of Ryanair.

The "shrinkage of hub and spoke operations needed because these capital intensive systems have lost their competitive edge” is a theme of Kahn (2005, p.9), which has been emphatic in the Irish case. Ryanair has been a pioneer in serving previously empty airports of which there are many in Europe inherited from military uses and airports built for development purposes by city and regional governments and some in private ownership. Lower fares, less delay and crowding, twenty-five minute turnaround times, lower landing charges, lower car parking charges and less walking and waiting times have contributed to a demythologisation of airports in Europe. This is a parallel with the demythologisation of Europe's national airlines. Routes dismissively described as "nowhere to nowhere" have succeeded because "small is beautiful" and a hub airport is an expensive bus stop. On Europe's largest and longest deregulated route, Dublin-London, the Heathrow hub has lost 
over half its market share to the smaller competing airports at Stansted, Gatwick, Luton and London City. There are also examples of airport competition between Glasgow and Prestwick, Stockholm and Skavsta, Oslo and Torp, Brussels and Charleroi and throughout the Ryanair network (Barrett, 2000). easyJet, the second major low cost airline in the deregulated European market, prefers to serve many of the traditional primary airports but not Heathrow where slot costs are high.

Travel agents, computer reservations systems and frequent flyer programs were found to be major post-deregulation barriers to contestability in the US case. Ireland had the benefit of second-mover advantage in dealing with these obstacles. Ryanair withdrew its product from travel agents and transferred to the Internet. It abolished its frequent flyer programme on the basis that passengers would vote for lower fares rather than the "gifts" alternative.

The three Irish airlines which entered the market after deregulation, Ryanair, Cityjet and Aer Arann, have projected passenger numbers in 2008 of 61 million compared to 10.5 million on Aer Lingus. With $85 \%$ of the passengers on new entrant airlines the abolition of barriers to market entry has had a major impact. "Ease of entry" may be somewhat euphemistic a description of this in economic theory however. As Kahn (1988) notes, deregulation "has been very hard on the industry itself; but it is the function of competition to be a hard taskmaster". Ease of exit has become a marked feature of Irish aviation since deregulation. The Aer Lingus exit from Dublin-Cork, the major internal route, was replaced by Aer Arann and Ryanair. The Aer Lingus exit from Shannon-Heathrow was replaced by Ryanair increased capacity to the other London airports and connections to other hubs by Cityjet to Paris and Aer Arann to Amsterdam from Galway. The Ryanair exit from Dublin-Cardiff was replaced by Aer Arann. While potential new entrants did not influence the markets from Ireland to other UK cities and mainland Europe after the Dublin-London deregulation for several years, actual new entrants had a marked impact. The time lag between potential and actual market entry has been reduced by airport competition, the Internet, the privatization of Aer Lingus and the reduction of both subsidization and regulatory capture. The Aer Lingus subsidies in the 1990s were sanctioned by the EU as a "one-off" and the airline now has a commercial mandate. While there are occasional nostalgic media references to Aer Lingus as "the national airline" the title is virtually meaningless. Goldman Sachs International (2004) found that full state ownership of airlines in Europe is now confined to a handful of small airlines in smaller countries.

The Irish aviation industry is larger by a factor of 33 since deregulation in 1986. Passenger numbers have increase from 2.2 million to an estimated 72 million. Fares have fallen, and productivity has risen dramatically. Post-deregulation new entrants account for $85 \%$ of the passengers carried and the previous monopolist has participated in each of these changes increasing both its profits and productivity. Kahn's policy prescriptions have been an outstanding success. His opponents, mostly the incumbent monopoly airline and its supporters, now readily acknowledge his genius. He revolutionised Irish aviation policy and heavily influenced wider economic policies. 


\section{Revolutions in economic policy}

The ideas of Alfred Kahn prompted a revolutionary change in Irish economic policy. A prized national institution, the national airline, was called into question. It was demythologized and its regulatory capture over policy was broken. It was privatized in 2006. Deregulation in the Ireland of 1984 was thus a major policy u-turn in an economy with huge economic problems. Airline deregulation was the start of a major period of policy changes in Ireland later in the 1980s such as restoring order in the public finances and reducing tax rates.

The ending of the Aer Lingus monopoly both in the market and in policy making recalls the words of Keynes (1936, pp.383-384) in his concluding pages of the General Theory.

"The ideas of economists and political philosophers, both when they are right and when they are wrong, are more powerful than is commonly understood. Indeed, the world is ruled by little else ... I am sure that the power of vested interests is vastly exaggerated compared with the gradual encroachment of ideas ... Soon or late, it is ideas, not vested interests, which are dangerous, for good or evil."

The support of Irish economists for the policies of Alfred Kahn continued a long tradition of involvement in policy issues. The history of Trinity College, Dublin (McDowell and Webb, 1982, p.189) records that its nineteenth century economists "were happiest in deriving economic principles from current practical problems of which Ireland furnished many in a particularly stark form”. The foundation of the Statistical and Social Inquiry Society of Ireland in the famine year of 1847 by John Kells Ingram and colleagues reflected the view that economics should serve the wider society. This was supported by economists in the USA and Ingram was elected an honorary member of the American Economics Association in 1891. Ingram and colleagues founded his Society some 38 years before the American Economics Association in 1885 and 44 years before the Royal Economics Society was founded in 1891. Ingram (1864) was motivated by the belief that economics should serve the wider community rather than occupy itself with dilettante statistics. The founders of the Statistical Society were moved by

"The pressure of social problems then imperatively demanding attention that led its youthful founders to attempt the establishment of such an institution ... It has not occupied itself with dilettante statistics, collected with no special purpose and tending to no definite conclusion. It has from the first applied itself, in the spirit of earnest enquiry, to the most important questions affecting the condition of the country. ... our business is to discover and demonstrate, by the application of scientific principles, the legislative action appropriate to each phase of society and each group of economic conditions. At what precise time, and in what particular form, our conclusions should be adopted in practice, is a question of political expediency which those who are acquainted with the varying exigencies of public life can determine better than we. But it is encouraging to know that in endeavouring by our researches and discussions to overthrow error and establish truth, we are labouring at no unpractical-no hopeless task; that any wise suggestion developed here may one day become a beneficent reality, a living agency for good; and that thus, without sitting on the councils of the State, or mingling in the strife of parties, we may, each of us, do something towards the improvement of the institutions of our country” (Ingram, 1864, p.13). 


\section{References}

Bailey, E. and J. Panzar (1981) "The Contestability of Airline Markets during the Transition to Deregulation,” Law and Contemporary Problems, 44: 126-145.

Bailey, E. and J. Williams (1988) "Sources of Economic Rent in the Deregulated Airline Industry,” Journal of Law and Economics, 31: 173-201.

Bailey, E. (1989) "Enhancing the Performance of the Deregulated Air Transportation System,” Brookings Papers on Economic Activity (Microeconomics), 113-5.

Barrett, S.D. (1990) “Deregulating European Aviation - A Case Study,” Transportation 16: 311-327

Barrett, S.D. (2000) “Airport Competition in the Deregulated European Aviation Market,” Journal of Air Transport Management, 6: 13-27.

Barrett, S.D. (2004) “The Sustainability of the Ryanair Model," International Journal of Transport Management, 2: 89-98.

Barrett, S.D. (2006) "Privatization in Ireland," in Kothenburger, M., Sinn, H-W, and Whalley, J. (ed.), Privatization Experiences in the European Union, MIT Press: Cambridge.

Barrett, S.D. (2007) Hub Airport Slots, Market Exit and Irish Regional Economic Development, Quarterly Economic Commentary, Winter: 63-79.

Barrett, S.D. (2008) “The Implications of EU/US Open Skies for the Irish Aviation Market,” forthcoming, Journal of Air Transport Management.

Barrett, S.D. and E. Curran (1984) "How to Halve the Cost of Air Fares in Europe," Management, July/August, 16-18 and December, 28.

Breyer, S. (1982) Regulation and its Reform. Harvard University Press: Cambridge.

Breyer, S. and R. Stewart (1992) Administrative Law and Regulatory Policy. Little, Brown and Company: Boston.

Byrne, P. (2004) Fuelled by Belief, The Cityjet Story. Liffey Press: Dublin.

Civil Aviation Authority (2006) “No-Frills Carriers: Revolution or Evolution,” CAP 770, London.

Civil Aviation Authority (2007) "Connecting the Continents, Long Haul Passenger Operations from the UK,” CAP 771. London.

Davy, J.E. (2006a) “Ryanair as a Consumer Growth Company,” Dublin.

Davy, J.E. (2006b) “Aer Lingus,” Dublin 
Doganis, R. (2001) The Airline Business in the $21^{\text {st }}$ Century. Routledge: London.

Doganis, R. (2006) The Airline Business. Routledge: London.

Goldman Sachs (2004) "Evaluation of Ownership Options Regarding Aer Lingus plc," Government Publications, Dublin.

Goodbody Economic Consultants (2005) “The Private Bus and Coach Sector in Ireland,” Dublin.

Government of Ireland (1985) "White Paper on Tourism Policy.”

Government of Ireland (1994) “Green Paper on Aviation Policy.”

Ingram, J.K. (1864) "Considerations on the State of Ireland," Journal of the Statistical and Social Inquiry Society of Ireland, iv, 13.

Kahn, A. (1987) “Deregulatory Schizophrenia,” California Law Review, 75: 1059-1068.

Kahn, A. (1988) "Surprises of Airline Deregulation," American Economic Review, 78: 316-322.

Kahn, A. (1988) “Airline Deregulation: A Mixed Bag, but a Clear Success Nevertheless,” Transportation Law Journal, 16, 229-251.

Kahn, A. (1989) “The Economic Theory of Regulation after a Decade of Deregulation," Brookings Papers on Economic Activity (Microeconomics), 59.

Kahn, A. (1989) "Enhancing the Performance of the Deregulated Air Transportation System,” Brookings Papers on Economic Activity (Microeconomics), 115-121.

Kahn, A. (1990) “Deregulation: Looking Backward and Looking Forward,” Yale Journal on Regulation, 7: 325-354.

Kahn, A. (1991) “Thinking About Predation - A Personal Diary,” Review of Industrial Organisation, 16: 137-146.

Kahn, A. (2004) Lessons from Deregulation. AEI-Brookings Institute: Washington.

Kahn, A. (2005) "Reforming the FCC and its Missions; Lessons from the Airline Experience,” Journal on Telecommunications and High Technology Law, 4: 43-58.

Keynes, J.M. (1936) The General Theory of Employment, Interest and Money. Macmillan: London.

Lee, J.J. (1989) Ireland 1912-1985, Politics and Society. University Press: Cambridge.

Levine, M. (1987) “Airline Competition in Deregulated Markets: Theory, Firm Strategy, and Public Policy,” Yale Journal on Regulation, 4: 393-494. 
Levine, M. (2007) "Regulation, the Market, and Interest Group Cohesion: Why Airlines Were Not Reregulated,” in Landy, M., Levin, M., and Shapiro, M. (ed.), Creating Competitive Markets, Brookings Institution: Washington.

McDowell, R.B. and D.A. Webb (1982) Trinity College Dublin 1592-1952: An Academic History. Cambridge University Press: Cambridge.

Morrison, S. and C. Winston (1989) Enhancing the Performance of the Deregulated Air Transportation System. Brookings Institute: Washington.

OECD (2001) “Regulatory Reform in Ireland,” Paris.

Peltzman, S. (1989) "The Economic Theory of Regulation after a Decade of Deregulation,” Brookings Papers on Economic Activity (Microeconomics), 1-59.

Ryanair (2008) “Investor Road Show Presentation,” January.

Share, B. (1986) The Flight of the Iolar, the Aer Lingus Experience 1936-1986. Gill and Macmillan: Dublin.

Taneja, N. (1983) “A Comparison of Airline Fares for Scheduled Services in European and US Domestic Markets," IATA Seeheim Aviation Seminar, (Fact Sheet No. 1, October 1984 and statement in Sunday Tribune, 18 December 1984).

Transamerica Airlines (1984) “Air Transport Bill will Eliminate Competition, Dublin,” 15 November. 